\title{
JUAN BONACCINI: A PESSOA E O PROFESSOR
}

\author{
Edrisi Fernandes
}

Cátedra UNESCO/Archai-Universidade de Brasília

Natal, v. 23, n. 41

Maio-Ago. 2016, p. 289-293

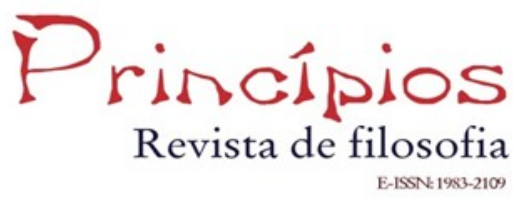


Conheci Juan Bonaccini de muitas formas. Na UFRN tive-o como professor em disciplinas ligadas a Aristóteles, Descartes, Hegel e Kant durante o período em que fiz graduação, especialização, mestrado e doutorado em filosofia. Quando iniciei o curso de filosofia eu já havia concluído graduação, especialização e mestrado em medicina, e trabalhava como médico da Marinha do Brasil, de forma que foi como alguém com certa maturidade que acompanhei as aulas de Juan, que tinha quase a mesma idade que eu. Em certo momento do curso tornei-me médico dele e da família - a esposa e mãe dos seus filhos começou a namorar com ele em uma festa do meu aniversário -, e nossa aproximação cresceu quando ele se tornou meu vizinho (morou por um bom tempo a menos de 5 minutos de caminhada de onde eu residia). Gostávamos ambos de um bom vinho tinto seco, de ler Borges e de filosofia alemã, de forma que, quando resolvi investigar as inquietações de Nietzsche como tema para o mestrado, e a filosofia de Schelling como tema para o doutorado, foi com naturalidade que me tornei seu orientando. Minha experiência na pós-graduação agradou tanto a mim quanto a ele; o resultado das pesquisas obteve uma excelente avaliação local e nacional, e ambos aprendemos muitas coisas com as investigações empreendidas. Tratava-se, ademais, da primeira turma de mestrado em filosofia da UFRN, e primeira turma do programa de doutorado integrado em filosofia da UFRN/UFPB/UFPE, de forma que a experiência tanto era desafiadora quanto inovadora.

Quando conheci Juan ele já era magro e com um pouco de cifose; cabeludo, tinha o topo da cabeça calvo como um franciscano, e ostentava uma barba enorme. À medida que os cabelos foram se rarefazendo ele foi desbastando a barba até abandoná-la; com a barba foram-se também os últimos acentos do sotaque do garoto portenho, ficando a herança fonética dos muitos anos de estudo na UFRJ (bacharelado, mestrado e doutorado em filosofia), com lenta e suave "contaminação" posterior pelo sotaque potiguar. Do ponto de vista linguístico, apesar de não fazer alarde do seu domínio de idiomas, sei que Juan conhecia os fundamentos do grego e tinha 
uma boa base do latim; lia sem problemas em francês e italiano e falava fluentemente inglês e alemão, além de conhecer as bases e algumas idiossincrasias e curiosidades do idioma russo. Tinha uma cultura literária muito boa, envolvendo escritores argentinos, brasileiros, espanhóis, anglo-saxônicos e os contistas e romancistas russos essenciais, fora muitos autores do Romantismo alemão. Era fã entusiasmado de - pelo menos - Francisco Suárez, William Shakespeare, J. W. von Goethe e Jorge Luis Borges. Proclamava-se agnóstico, mas conhecia a fundo a dogmática cristã, e o futebol certamente contribuiu para a preservação de sua argentinidade, enquanto brasileiro de adoção. Suas ideias sobre política eram demasiado embasadas para que se apaixonasse pela "politicagem" do cotidiano, e em minha avaliação ele era uma das poucas pessoas capazes de encontrar algum equilíbrio entre o socialismo e o liberalismo, e de propor algo exequível entre a utopia o pragmatismo.

Como orientador, era extremamente atento, minucioso, dedicado, rigoroso; nunca detectei nele, contudo, qualquer traço de petulância. Dedicava especial atenção a cada um dos seus orientandos, em suas habilidades, limitações e aspirações individuais, e não media esforços para tornar factível e respeitável cada projeto de pesquisa. Esperava do orientando o mesmo perfeccionismo que buscava nos seus estudos e na escrita; era certamente um entusiasta da releitura e da reescritura, que exercitava com notável paciência. Esperava que aquilo que houvesse de mais importante na bibliografia fosse conhecido e bem assimilado pelo aluno, mesmo que não viesse a ser citado. Estimulava leituras atentas, demoradas e detalhadas das fontes primárias antes de qualquer "contaminação" pelos comentadores, e incentivava o estudo de interpretações muito variadas, para que a discussão fosse enriquecida mediante a polissemia das abordagens, sem que houvesse, contudo, perda do foco almejado, bem delimitado pela atenção cautelosa e continuada aos conceitos envolvidos, sendo que tinha peculiar apreço pelos desenvolvimentos da ideia de Begriff desde as "Palestras sobre Lógica de Kant", que romperam com o sentido geral que chegara até 
Christian Wolff. Talvez o cuidado no tratamento dos conceitos fundamentais associados aos temas das investigações que orientava ou conduzia fosse aquilo que "costurava" o modo como empregava, com precisão, os instrumentos filosóficos hauridos de Aristóteles, Sexto Empírico, Suárez, Descartes, Vico, Kant, Hegel e Strawson, entre outros; ademais, também admirava e conhecia suficientemente os visionários para "curtir" leituras e discussões de Hamann, Baader, Nietzsche, Thoreau e Foucault, por exemplo.

Teve uma bela vida, consagrada à família, à amizade, à intelecção, à reflexão, à crítica, ao debate de ideias. Sua habilidade argumentativa, muito bem concatenada, era atraente e elegante, como se pode ver mesmo em textos simples como os seus "Do problema do ensaio - do ensaio como problema" (1992; publicado em 1994) e "Podemos censurar moralmente os outros?" (2004). Se não fosse tão perfeccionista, e adepto do estudo aprofundado e extenso de temas difíceis - como os fundamentos, as particularidades, as repercussões da filosofia prática de Kant (tema de investigações de uma vida inteira), a interpretação hegeliana do problema cético ${ }^{1}$, e questões relativas à metafísica do tempo ${ }^{2}-$, teria certamente deixado muitas obras do porte dos seus livros A dialética em Kant e Hegel (2000) e Kant e o problema da coisa em si no Idealismo Alemão

\footnotetext{
${ }^{1}$ Veja-se, por exemplo, seu ensaio "O conceito hegeliano de 'Fenomenologia' e o problema do Ceticismo" (Veritas, 2006), e "Hegel e o problema do Ceticismo" (Revista Eletrônica Estudos Hegelianos, 2005).

2 Favorecidas pelo menos desde as análises fundamentadoras do seu ensaio "Sobre o tempo" (Princípios, 1998), passando pela "Breve consideração sobre o problema da tese da aprioridade do espaço e do tempo" (Studia Kantiana, 2000), por "Tempo e eternidade: excurso sobre a concepção agostiniana de tempo" (Crítica, 2004) e pelas "Anotações sobre a Metafísica Dohna (1792/ 1793)" (Philosophica, 2007), para citar apenas alguns marcos, incluindo minha própria tese de doutoramento, Antecedentes histórico-filosóficos da problemática do tempo e do mal no Freiheitsschrift de Schelling: aproximações gnósticas" (UFRN/UFPB/UFPE, 2010) - impensável sem a esmerada orientação de Juan - e chegando pelo menos até a orientação da tese de doutoramento Metafísica do tempo presente: sobre o programa de Walter Benjamin a uma filosofia vindoura", de Francisco Ramos Neves (UFRN/UFPB/UFPE, 2014).
} 
(2003). A vasta coleção de artigos que produziu merecia já ter sido enfeixada em algumas coletâneas.

Deixou um amplo legado de contribuições acadêmicas; além dos muitos textos avulsos, publicou quatro livros (dois individuais e dois como organizador), além de ter se dedicado ativamente ao desenvolvimento e à consolidação do ensino superior de Filosofia, mormente no Nordeste do Brasil. Contribuiu para a formação de várias dezenas de alunos, incluindo seus muitos e privilegiados orientandos, em quem deixou a lembrança de um professor apaixonado pelo seu ofício e pela filosofia, um verdadeiro amante da sabedoria, um autêntico filósofo.

Juan tinha uma saúde frágil, e a aparente desmesura de seu temor de adoecer (e, também, de ver familiares doentes) era nele sábia estratégia de preservação. Era um paciente extremamente "kantiano" - muito disciplinado e fiel cumpridor das recomendações terapêuticas. Com ele, aliás, aprendi a valorizar as possíveis contribuições do "raciocínio médico" para as ciências humanas, em leituras partilhadas dos médicos filósofos Sexto Empírico, Locke e Schelling.

Sua última empreitada intelectual foi, apropriadamente ao seu adoecimento consumptivo e à séria e demorada crise brasileira, uma investigação sobre o estatuto filosófico dos milagres, da qual fizeram parte suas publicações intituladas "Kant e o estatuto dos Milagres" (2011) e "Kant's account of miracles in his Lectures on Metaphysics" (2015). Sua lucidez já faz falta entre nós. 